\title{
14
}

\section{TEACHING IMMERSIVE JOURNALISM}

\author{
Turo Uskali and Pasi Ikonen
}

This chapter draws from a study designed for this volume. Its main purpose was to answer two questions: 1) where has immersive journalism been taught? and 2) how to best teach immersive journalism?

This chapter adds value by offering an overview and fresh insights from some of the leading journalism educators in the world, focusing on the interplay of emergent technologies and journalism, especially in relation to immersive journalism. So far, journalism educators have not been at the forefront of immersive journalism studies, although journalists (Watson 2017; Aitamurto 2019), content (Jones 2017; Bosworth \& Sarah 2019), and audiences, especially students (Sundar et al. 2017; Shin \& Biocca 2018), have received attention.

Traditionally, journalism education has been rather slow in reacting to many technological changes (Deuze 2006). The change needed for journalism education has been emphasized from varying perspectives. Angus and Doherty (2015) have argued for design skills for students to be able to better understand digital platforms. Robinson (2013) has demanded radical changes in core curricula and reporting classes, arguing for teaching "journalism as process". Although technology adoption into journalism curricula has been slow, fresh entrants to the news industry have also been criticized by working veterans for lacking traditional skills, which have been superseded by technological emphasis in the curricula (Ferrucci 2018).

We first map the journalism educators that have been teaching Immersive Journalism courses. We proceed by giving some background information about the five journalism teachers chosen as interviewees. Next we present our results, and finally we summarize and discuss our results in the Conclusions section. 


\section{Mapping immersive journalism educators}

To begin seeking out those journalism educators who have used immersive technologies in their classes, a desk study was implemented. We searched for global course listings and public announcements in English as well as online news articles on the topic using internet search engines. In addition, we also used the snowball sampling method (King et al. 2019,62) during the interviews, and asked each interviewee to recommend another knowledgeable interviewee in terms of immersive journalism education.

We could find only a few teachers and courses. In reality, there are most probably many more, but nevertheless this initial listing (see Table 14.1) sketches the current status of the field, at least in the English-speaking parts of the world. Many of the courses have been one-time tryouts or experiments.

To understand how immersive journalism is being taught, a closer look at practice is needed. For this chapter, we conducted a set of interviews with five immersive journalism teachers from five different countries. The interviews were semi-structured (Ayress 2008, 810) and lasted from 25 minutes to one hour. They were conducted face-to-face (one interview) and via phone and video calls (four interviews). Table 14.2 presents the interviewees and their courses in their respective higher education institutions. The interview transcripts were analyzed in a qualitative manner using content analysis, and paraphrases related to teaching virtual reality (VR) were searched for.

In this next section we introduce the five courses in question and their instructors.

Associate Professor of Practice Robert Hernandez from the University of Southern California, Los Angeles (USC) has been teaching immersive technologies for journalism since 2012. He began with augmented reality (AR) before starting the ongoing VR course in 2015. At the same time, TV documentarist Nonny de la Peña, the "godmother" of immersive journalism, and Palmer Luckey, who later founded the head-mounted display company Oculus, were working at the USC's Mixed Reality Lab. During recent years, Hernandez and his students have won several awards, especially thanks to their Jovrnalism app that includes several immersive journalism stories. Jovrnalism has received awards from the Online News Association, the Association for Education in Journalism and Mass Communication, the Los Angeles Press Club, The Webby Awards, and the World Journalism Education Congress. In addition, from March to April 2017, Hernandez ran the very first MOOC (massive open online course) on immersive journalism, "Intro to Immersive Journalism: Virtual Reality \& 360 video". It was offered by the Knight Center for Journalism in the Americas at the University of Texas at Austin. During the course, students producedVR, AR, and mixed reality productions, some of which ended up on the project's website and were distributed further.

Senior Lecturer Ben Stubbs of the University of South Australia (UniSA) at Adelaide in Australia created the course "VR Storytelling" in 2017. It is being taught for the third time in autumn 2019. In the course, students learn aboutVR in general, the use of 360-degree cameras, editing, creating their own stories, and 
TABLE 14.1 A selection of journalism schools teaching immersive journalism

\begin{tabular}{|c|c|c|c|c|}
\hline Country & University & Teacher(s) & $\begin{array}{l}\text { Course/class (or part of a } \\
\text { course) }\end{array}$ & Active? \\
\hline Australia & $\begin{array}{l}\text { University of South } \\
\text { Australia }\end{array}$ & Ben Stubbs & $\begin{array}{l}\text { Virtual Reality } \\
\text { Storytelling }\end{array}$ & 2017 \\
\hline Belgium & $\begin{array}{l}\text { University of } \\
\text { Antwerp }\end{array}$ & $\begin{array}{l}\text { Kristof } \\
\text { Timmerman } \\
\text { and others }\end{array}$ & $\begin{array}{l}\text { Summer course } \\
\text { "Storytelling in Virtual } \\
\text { Reality" }\end{array}$ & 2019 \\
\hline Denmark & $\begin{array}{l}\text { Danish School } \\
\text { of Media and } \\
\text { Journalism }\end{array}$ & Mette Sejsbo & $\begin{array}{l}\text { Virtual Reality } \\
\text { Storytelling }\end{array}$ & $2018-$ \\
\hline Finland & $\begin{array}{l}\text { University of } \\
\text { Jyväskylä }\end{array}$ & Panu Uotila & $\begin{array}{l}\text { Part of a Multimedia } \\
\text { Journalism course }\end{array}$ & 2018 \\
\hline \multirow[t]{4}{*}{ Norway } & \multirow[t]{2}{*}{$\begin{array}{l}\text { University of } \\
\text { Bergen }\end{array}$} & \multirow[t]{2}{*}{ Lars Nyre } & $\begin{array}{l}\text { Journalistic Prototyping } \\
\text { (VR journalism using } \\
\text { Samsung Gear) }\end{array}$ & 2018 \\
\hline & & & $\begin{array}{l}\text { Design for Media Use } \\
\text { (focus on VR narratives } \\
\text { for HTCVive) }\end{array}$ & 2019 \\
\hline & \multirow[t]{2}{*}{$\begin{array}{l}\text { University of } \\
\text { Stavanger }\end{array}$} & \multirow[t]{2}{*}{$\begin{array}{l}\text { Sigmund } \\
\text { Trageton and } \\
\text { others }\end{array}$} & $\begin{array}{l}\text { Part of a Multimedia } \\
\text { Storytelling course }\end{array}$ & 2018 \\
\hline & & & $\begin{array}{c}\text { Part of an Audiovisual } \\
\text { Storytelling course }\end{array}$ & 2019 \\
\hline \multirow[t]{2}{*}{ Sweden } & \multirow[t]{2}{*}{$\begin{array}{l}\text { Södertorn } \\
\text { University }\end{array}$} & \multirow[t]{2}{*}{$\begin{array}{l}\text { Malin Picha } \\
\text { Edwardsson } \\
\text { and others }\end{array}$} & $\begin{array}{l}\text { Part of the Storylab } \\
\text { project }\end{array}$ & 2015 \\
\hline & & & $\begin{array}{l}\text { Part of a course at the } \\
\text { Media Technology } \\
\text { department }\end{array}$ & 2019 \\
\hline \multirow[t]{5}{*}{$\begin{array}{l}\text { United } \\
\text { States }\end{array}$} & $\begin{array}{l}\text { University of } \\
\text { Southern } \\
\text { California, } \\
\text { Annenberg } \\
\text { School of } \\
\text { Communication }\end{array}$ & $\begin{array}{l}\text { Robert } \\
\text { Hernandez }\end{array}$ & $\begin{array}{l}\text { Emergent Technologies in } \\
\text { Journalism }\end{array}$ & $2012-$ \\
\hline & Stanford University & $\begin{array}{l}\text { Geri Migielicz, } \\
\text { Janine Zacharia }\end{array}$ & $\begin{array}{l}\text { Immersive Journalism } \\
\text { class }\end{array}$ & 2016 \\
\hline & Syracuse University & Dan Pacheco & $\begin{array}{l}\text { Virtual Reality } \\
\text { Storytelling }\end{array}$ & $2015-$ \\
\hline & $\begin{array}{l}\text { Hofstra University } \\
\text { School of } \\
\text { Communication }\end{array}$ & Aashish Kumar & $\begin{array}{l}\text { Virtual Reality } \\
\text { Storytelling }\end{array}$ & 2017 \\
\hline & $\begin{array}{l}\text { University of } \\
\text { California, } \\
\text { Berkeley }\end{array}$ & $\begin{array}{c}\text { Melissa Bosworth, } \\
\text { Lakshmi Sarah }\end{array}$ & $\begin{array}{l}\text { Workshop: VR: } \\
\text { Immersive 360-Degree } \\
\text { Video Storytelling }\end{array}$ & $2018-$ \\
\hline $\begin{array}{l}\text { United } \\
\text { Kingdom }\end{array}$ & $\begin{array}{l}\text { Coventry } \\
\text { University \& } \\
\text { Birmingham } \\
\text { City University }\end{array}$ & Sarah Jones & $\begin{array}{l}\text { Part of Innovation } \\
\text { Journalism courses }\end{array}$ & $2015-$ \\
\hline
\end{tabular}


ethical questions related to this form of storytelling. Stubbs has acquired AUD 50,000 in grants to explore VR in journalism education. The course won the 2018 Innovation in Journalism award from the Journalism Education and Research Association Australia, awarded by The Guardian. The university is currently the only one in Australia with a Practical VR Journalism course. The course is 12 weeks long (with a two-hour seminar every week) and has 15 students from Journalism and Media Arts. They use seven Insta 360 One cameras and have created their own editing software Immerse, which enables the use of interactive storytelling for 360-degree videos. As coursework, students produce six-minute videos with interactivity included.

Lecturer Mette Sejsbo of the Danish School of Media and Journalism (DJMX) at Copenhagen in Denmark teaches in the Department of TV and Media Direction. They provide basic training in producing and directing journalistic and documentary productions in VR, more specifically 360-degree videos. The course was run for the first time in 2017 with 40 students. The intensive course lasted for three weeks, focusing on creativity. In 2018, the VR workshop was held as part of a six-week Documentary course. During the course, the students used ten sets of Samsung equipment, including a phone, a pair of VR glasses, and a camera. The students produced documentaries and made one scene from the film also for VR. Sejsbo teaches the course with other lecturers as well as some outside visitors, for example former students and Danish Broadcasting Company journalists.

Senior Lecturer Malin Picha Edwardsson of Södertörn University at Stockholm, Sweden has taught courses that incorporate new technology, including VR, into journalism classes. While working at KTH Royal Institute of Technology in Stockholm, she taught in a Storylab class (Hultén \& Picha Edwardsson 2017) in cooperation with Stockholm University. In this class, Media Technology Engineering students worked together with Journalism students, creating stories using different technologies. One group used VR to tell a story about parental leave. The course started with five weeks of lectures, followed by a workshop. They then worked eight weeks on the group projects.

Assistant Professor Sigmund Trageton of the University of Stavanger in Norway teaches VR and 360-degree filming as part of an Audiovisual Storytelling course. The course is for third-year bachelor students of Television and Multimedia Production. The course lasts the whole autumn term, and students acquire ten points in the European Credit Transfer and Accumulation System (ECTS) from it. The section on multimedia, in which VR is introduced, takes about 40 percent of the time of the full course. There are 16 students in the class this year, and Trageton is leading the course with two colleagues. The course combines lectures, seminars, and workshops. They are equipped with one GoPro Omni camera, Kolor stitching software, and they use Premiere Pro and Pro Tools for editing. In 2018, Trageton and Espen Reiss Mathiesen taught a similar but smaller-scale VR class for Journalism and Television Production students, as part of a Multimedia Storytelling course.

Having introduced our interviewees, we present the results from the qualitative interviews. We identify some recurring themes, including practical skills, 
TABLE 14.2 Immersive journalism educators interviewed

Interviewee and institution

Robert Hernandez

Associate Professor of Practice

University of Southern California (USC)

Ben Stubbs

Senior Lecturer

University of South Australia (UniSA)

Mette Sejsbo

Lecturer

Danish School of Media and Journalism

(DJMX)

Malin Picha Edwardsson

Senior Lecturer

Södertörn University

Sigmund Trageton

Assistant Professor

University of Stavanger
Course description

Journalism course. Using VR, AR, and mixed reality technologies.

VR Storytelling course since 2017. 12-week course with 15 students producing 360degree videos with interactivity.

Virtual Reality Storytelling with varying forms. Currently as a one-week part of a larger Documentary course.

Introducing VR as a part of a more general Journalism and Media Technology course.

Introducing 360 filming and VR as a part of a course on Audiovisual Storytelling. One student group doing their coursework as a 360-degree video.

multidisciplinary cooperation, challenges with technology and time, course updating, larger questions to be addressed, and selecting the right technologies for classes. A few main challenges concerning teaching were also highlighted: learning the technology, motivating students to invest in the medium, time constraints, and the lack of examples from other universities.

\section{The challenge of emergent technologies in teaching}

How immersive storytelling is taught varies in scale and style. Reading the interviews reveals how teachers emphasize the importance of a hands-on approach and the role of students in learning. While immersive technologies are new to most students, enough time is required for them to be able to try out the equipment, experiment with filming in 360-degrees and work through the difficulties posed by new hardware and software. At the same time as students are learning the equipment, it is aging quickly. Most mid-range cameras used five years ago do not offer sufficient quality anymore.

Thus, one challenge is how to enable students to learn valuable skills and competences that are not tied to specific equipment. Many interviewees noted the variability of the hype around VR and changing forecasts on whether the technology will remain relevant in journalism or be forgotten. Nevertheless, students can learn valuable things from these courses, as was noted by Ben Stubbs and Sigmund Trageton. 
During two years of teaching VR at UniSA, Ben Stubbs has noted the value of practical skills for students. They start with an introduction, talking aboutVR's history and its connection to journalism. The next two weeks are spent learning the cameras, followed by a week of learning how to edit in Premiere Pro. The following weeks are dedicated to using their own editing software Immerse, interactivity, ethics, troubleshooting, and visiting an industry partner. The rest of the time is left open for students to work on their projects.

The UniSA course is taught with two teachers equally sharing the teaching load. The teachers have found that it is also beneficial to join each other's seminars for learning. Ben Stubbs notes the benefit of the small class size. Giving a strong foundation for the basic elements of 360-degree storytelling is crucial, so that the students are able to produce high-quality works. Before they start working on actual footage, the students do a written assignment, where they go through a set of questions, including why the story suits VR, what the role of the viewer is going to be, how the shots are planned, how interactivity will be used, and whether the topic could be filmed in another way.

Similarly, at the University of Stavanger, the VR part of the course, led by Sigmund Trageton, begins with a historical perspective, examining the differences in the VR medium compared to other formats. Then it proceeds to workshops about the equipment and software, and finally a course assignment for a real-life client. Although the end product of the assignment is fact-based immersive storytelling, it is not strictly a journalistic product, as it is aimed as educational material for eighth-grade primary school students.

\section{Multiple teacher roles}

Immersive journalism teachers may have multiple roles. During the time Robert Hernandez has been teaching his course since 2012, he has developed special methods and pedagogical insights for higher education that deserve to be explained in detail and at length. His teaching strategy mixes journalistic, managerial, diplomatic, and entrepreneurial skills in a way that could be seen as a rarity or even unique in journalism education.

First, as an educator he works like a journalist.

I'm still a journalist. I'm still looking at when the story or a trend is happening. And I find a way [...] As a reporter, I get informed. It is an informed, educated hunch. Right, so I have learned enough. If I start to think that I know all the answers without interviewing and learning [from] the community, that's the problem.

Second, Hernandez says that he has applied previous managerial knowledge to his Journalism courses. This could also be interpreted as part of an entrepreneurial mindset. Giving the course participants autonomy in their work is one important aspect. 
Third, he gives a lot of power and trust to his students. He has tried to work with his colleagues, inside industry and inside the university, but it did not work out.

They [students] bring us the skills and passions and they produce things. Even if I have a really creative imagination [and a] thinking, innovative mind, they bring it forward. We bring each other forward.

Hernandez acknowledges that if one gives too much freedom to the students it could paralyze them, so it is important to find the right balance.

So, I found ways to put a framework around it. Okay, you have a canvas about homelessness. You have a canvas [about] making it work with this media company. These are the limitations, but there is still this freedom and those limitations to create, but it is not paralyzing.

In addition, he says that the students are also the key to changing the industry in the near future.

My students that may have graduated, let's say, five years ago, are eventually going to be the boss. And they're going to apply the mindset there. So playing the long game and hopefully inspiring and innovating the media companies that are slow to do that.

As good examples of news media organizations that are constantly innovating, Hernandez mentions The New York Times, USA Today, and Al Jazeera.

Fourth, Hernandez clearly works like a producer and a hub-builder. Even if his employer is one of the best-funded universities in the world, his courses have not enjoyed vast resources. They have needed to create their own innovator hub strategy, bringing together an academic institution, industry, and media partners. He constantly connects media organizations and technology companies together in order to test new emergent technologies via journalism education.

So, the traditional professor-academic industry relationship was to ask industry, "What do you need?" I would train people to give them. Industry now, [it] does not know what it needs. It is not funded enough to think ahead. So, I'm taking advantage of that and saying, "I know what the industry needs". I'm going to create. I wanna be the R\&D for the industry.

Hernandez and his students have freedom to experiment with new formats. They can also work simultaneously with industry partners that usually do not cooperate. For example, in the case of President Donald Trump's inauguration and the women's march in January 2017, Hernandez and his students produced content both for The New York Times and National Public Radio (NPR). In addition, Samsung funded the 360-degree cameras for the students. 
To sum up, Hernandez's teaching strategies could be defined as long-term innovation pedagogy. Even if emergent technologies come and go and cycle through different maturation phases, journalism schools could be innovative test labs for the future of journalism. This could be done with the help of the students' creativity and risk-taking, supporting media-tech industry hubs, and the journalist/manager leading the project.

\section{Multidisciplinary approach}

Australian Ben Stubbs argues that bringing in students from different disciplines has been beneficial. Students with Communication and Media degrees are joining the course alongside Journalism majors. Stubbs finds the whole nature of immersive journalism so different from conventional journalistic storytelling, and that the different skillsets brought by students benefit the group work.

For Senior Lecturer Malin Picha Edwardsson, group work combining four Engineering students with one Journalism student proved to be challenging. She attributes this to the students from different backgrounds "speaking in different languages", and having trouble with group collaboration: "By the time we got them [the groups] to actually function, then time had run out for making the final result". Obviously, this was a valuable learning experience for the students.

In their Storylab class project, Edwardsson and her colleagues gained insights into various challenges that new technology can introduce. As immersive technologies were introduced on a small scale as part of a larger class, technical issues often came up. Lack of time to test the equipment as well as teach how to use it can frustrate students, and the full potential for learning storytelling is missed. Moreover, VR was only part of the course, and learning the technology became a major challenge for successful work. The students did not have the right equipment nor anyone to teach them how to work with that technology properly, so they were facing a tough test.

Getting new software to work also caused problems during the first year of Sejsbo's course at DJMX. The programs worked slowly, causing students to spend hours of time just waiting. Taking the VR class for the first time, Sejsbo's students were not very excited. The equipment was not working properly, and for some groups not at all: "So their experience of, 'Can this do something?' was very limited - it was an eye-opener to all the difficulties".

In the following year, VR storytelling was incorporated into a longer sixweek course in which the students produced flatscreen documentaries. They were instructed to make an extra VR production of one scene from the documentary. This time, as students were occupied in working with the flatscreen documentaries, they did not put energy into the VR production, and felt that it was an "irritating appendix". In autumn 2019 the course has been adjusted again so that the last week of the Documentary course will be reserved forVR storytelling. Based on the previous experiences, the teachers are now very aware of the limitations with the equipment, and are aiming to avoid frustrating the students. 
Sigmund Trageton has found that the students need more time for the planning phase of the filming. Another point he notes is understanding how to structure stories with this technology.

I don't think the students knew how much work it would take, from a technical point of view. And maybe they also thought that it would be easier in a way, to tell compelling stories, because of the medium itself [...] If we want to have a better quality of the end product, we also need to give them more time and more teaching about this medium. But like the plan is now for this semester, it's [that] we have so much other things to teach them.

Ben Stubbs has recognized that there is much to be taught in a short time. Overburdening the students with too much information is a risk, he states. It is challenging to get students to handle all the storytelling aspects, including the use of interactivity.

Because a lot of what they are going to learn comes from experimenting, during that month during the teaching break, where they are going to take the camera and go out and make some mistakes. And they come back to the edit suite, and they realize, "Hey, we should've done this." So, it's kind of balancing.

\section{Bigger questions at play, such as ethics}

Stubbs noted that setting proper requirements for the students' coursework is important. Previously, students were producing only linear stories. From 2019, the UniSA course requires use of interactivity. Students can add branching storylines in the Immerse editing application using hot spots that can be accessed via focusing the user's gaze on them.

Just playing with that idea, that what a story in VR can be. That journalism normally is that beginning, middle, and end, but this allows [them] to do something different.

Even though the course held by Mette Sejsbo at DJMX is an introduction to the technology, bigger questions are immediately also at play. These include topics such as the role of VR in journalism and what it should be used for. Students are eager to discuss these dilemmas.

Final coursework from students of Sejsbo's documentary class in 2018 was very varied in quality and style. Some of the best works included small stories where the viewer was taken into a place not very well-known to many, for example showing a wheelchair-user's view of the world. For Sejsbo, an intriguing aspect in teaching VR storytelling is the question of what it means for our way of telling stories. She asks what the effects of this are on learning and engaging people: 
If we want to speak so much as VR supposedly does, or that's what the producers hope it does, engage people more, what is the cost on the information level? [...] And also, to say, if we use VR, if we go for it, what kind of things should it be for?

Therefore, when teaching VR journalism or documentary-making, it is important also to consider why the format is being used. Sejsbo wants to teach the students to tell stories in a new way and understand 360-degree stories and their consequences in portraying our world. Finding the proper narrative tools for VR journalism is important.

Sigmund Trageton feels that the students need to experience the medium in order to understand it properly.

I think if you're gonna use VR or 360, you have to experience it in a headmounted display. If not, it's a little bit, you know, in between.

Ethical questions are part of the UniSA coursework. Stubbs wants the students to be aware of what the so-called gray areas in VR ethics are. Stubbs hopes that students make deliberate choices concerning ethics while they produce their own course assignments.

Stubbs states that the notion of what a journalist is can and should be questioned to some extent. As future roles of journalists are still debatable, journalism educators should remain alert to how the field is changing.

\section{Selecting the right technologies to work with}

There are emergent technologies coming up all the time. For these technologies to be picked up by Hernandez's class at USC, they need to be interesting, currently available, affordable, modifiable, and not locked to a specific environment. The class should be able to make their own product and brand it as such. In essence, Hernandez's class is not trying to come up with new technologies but adapting affordable emergent technologies and innovating new forms for journalism.

I focus on all the emergent technologies, [with] immersive as a focus [...] 360-degree video is still a valid platform, [an] incredible medium that can tell stories no other medium can tell. It is also a fantastic way to onboard people to the immersive platform.

UniSA students appreciate the future-oriented nature of the VR course, Stubbs notes. Even if the hype for VR journalism has cooled down in recent years, Stubbs sees learning 360-degree storytelling as an advantage for students' future careers. These kinds of skills might not be in use in many newsrooms, but having a "bag of tricks" that the newsrooms do not yet possess might come in handy later on. 
Trageton emphasizes that teaching about VR also teaches students about other forms of audiovisual communication that they are learning at the same time. Making the students conscious about the differences in each medium takes time.

So, then my main philosophy is that $[\ldots]$ by learning this new medium, they learn that it's a different medium, and by learning a different medium, they also learn more about the older media, like film and still photography [...] I think it needs quite a long time for the students to understand this.

\section{Future prospects}

In 2019, as the VR hype cooled down, Hernandez again focused more on AR in his Emergent Technologies class. Hernandez is convinced that, with fast mobile $5 \mathrm{G}$ internet networks, immersive technologies will prevail, even though quality content that excites the average consumer is still needed for a breakthrough.

$\mathrm{AR}$, for me and all in the industry, is the long game. That will have more mass adoption than VR [...] And when we are living in [a] mobile first world, AR is mobile-friendly.You already have the devices. So, then we talk about what kind of experiences you do wanna create and what kind of assets you need to create.

Hernandez noted that AR technology has matured on a variety of fronts, including mainstream developer platforms available from Apple and Google as well as Unity plugins. Making 3D models is becoming easier and more accessible. To also investigate how immersive journalism is distributed, Hernandez is utilizing different platforms, including Snapchat.

Due to the evolving nature of the technology, Stubbs notes, the UniSA course requires constant updating, both of the equipment and of what to teach.

It does require more attention than other courses. Just in terms of tweaking and making sure that we are aware of new things in the industry as well. Because, even from the lectures I wrote three years ago, things have changed quite a lot. I think the optimism has dimmed a little.

On another note, according to Stubbs, course expenses have come down. For example, the cameras are much cheaper than three years ago, the editing is easier, and the picture quality is better.

To develop teaching, getting insights from other universities would be beneficial. In Stubbs' view, this would enable him to benchmark courses and also to collaborate. Currently, UniSA is the only Australian university with a PracticalVR course.

Trageton remains unsure about continuing the 360-video part of the course during the coming years. They might add more emphasis on the medium, buy some cheaper, handier cameras, or, alternatively, remove it completely to have more time for other parts of the course. 


\section{Conclusions}

From web-based searches and five experts' semi-structured interviews, we can argue that teaching immersive journalism is still a rarity in the world. Journalism educators have tended to be followers and not proactive innovators in terms of adapting new tools or practices in their education work (Deuze 2006). This is also true in terms of immersive journalism. Technology alone, be it VR or some other, will not save journalism or journalism education (Creech \& Mendelson 2015); but still we argue that it would be unwise to ignore any new technologies' potentiality for transforming or at least influencing journalistic storytelling.

Nevertheless, according to our findings, there has been a small number of journalism schools and professors willing to be at the forefront of VR journalism, 360-degree journalism, and even AR journalism. It seems that leading journalism schools, especially in California, have adapted and adopted the idea of Deuze's (2006) innovator model in their journalism education. The Annenberg School of Communication at the University of Southern California in Los Angeles, Stanford University's Virtual Reality Lab's collaboration with Stanford's Journalism Master of Arts (MA) program, and also the School of Journalism at the University of California, Berkeley, have all taught immersive journalism. Not surprisingly, many of the first VR companies were started either in Silicon Valley or near Los Angeles (Lanier 2018; Bailenson 2018).

Moreover, in other parts of the world, from Australia to the United Kingdom and Nordic countries, immersive journalism has been in the curricula. One of the shortcomings of this chapter clearly is that we did not get any information about immersive journalism teaching in Asia, Africa, or South America. Further explorations of global immersive journalism education are needed.

Five immersive journalism teachers from Australia, Denmark, Norway, Sweden, and the United States were interviewed, with the main question being how to best teach immersive journalism. The answer was manifold. In other words, there is a great variety of models of how to teach immersive journalism, but they all relate to innovation pedagogy, which emphasizes exploration and risk-taking. As immersive journalism is still small in its scope, only a few universities have created dedicated courses. There is room for the development of VR journalism around the world; for example, Stubbs (2018) has argued that mastering VR techniques would be a valuable asset for Australian journalism students.

Clearly, we need more research about the importance and role of online communities in terms of adapting new emergent technologies in journalism.

\section{References}

Aitamurto, Tanja. 2019. "Normative Paradoxes in 360-degree Journalism: Contested Accuracy and Objectivity." New Media \& Society 21(1), January: 3-19. doi:10.1177/ 1461444818785153

Angus, Daniel \& Skye Doherty. 2015. "Journalism Meets Interaction Design: An Interdisciplinary Undergraduate Teaching Initiative." Journalism \& Mass Communication Educator 70(1), March: 44-57. 
Ayress, Lioness. 2008. "Semi-Structured Interview." In: L.M. Given (ed.), The SAGE Encyclopedia of Qualitative Research Methods Volumes 1-2. Thousand Oaks, CA: SAGE.

Bailenson, Jeremy. 2018. Experience on Demand: What Virtual Reality Is, How It Works, and What It Can Do. 1st ed. New York: W.W. Norton \& Company.

Bosworth, Melissa \& Lakshmi Sarah. 2019. Crafting Stories for Virtual Reality. Abingdon-onThames, UK: Routledge.

Creech, Brian \& Andrew L. Mendelson. 2015. "Imagining the Journalist of the Future: Technological Visions of Journalism Education and Newswork." The Communication Review 18(2), May: 142-165.

Deuze, Mark. 2006. "Global Journalism Education: A Conceptual Approach.” Journalism Studies 7(1), August: 19-34.

Ferrucci, Patrick. 2018. “We've Lost the Basics': Perceptions of Journalism Education From Veterans in the Field." Journalism \& Mass Communication Educator 73(4), December: 410-420. doi:10.1177/1077695817731870

Hultén, Gunilla \& Malin Picha Edwardsson. 2017. "Storylab Lessons: A Collaborative Project Between Courses in Journalism and Media Technology." Nordicom Review 39(1), May: 3-17.

Jones, Sarah. 2017. "Disrupting the Narrative: Immersive Journalism in Virtual Reality." Journal of Media Practice 18(2-3), July-November: 171-185.

King, Nigel, Christine Horrocks, \& Joanna Brooks. 2019. Interviews in Qualitative Research. 2nd ed. London: SAGE.

Lanier, Jaron. 2018. Dawn of the New Everything: Encounters with Reality and Virtual Reality. New York: Henry Holt and Co.

Robinson, Sue. 2013. "Teaching 'Journalism as Process': A Proposed Paradigm for J-School Curricula in the Digital Age." Teaching Journalism \& Mass Communication 3(1), Winter: 1-12.

Shin, Donghee \& Frank Biocca. 2018. "Exploring Immersive Experience in Journalism." New Media \& Society 20(8), August: 2800-2823. doi:10.1177/1461444817733133

Stubbs, Ben. 2018. "Virtual Reality Journalism: Ethics, Grammar and the State of Play." Australian Journalism Review 40(1), July: 81-90.

Sundar, S. Shyam, Jin Kang, \& Danielle Oprean. 2017."Being There in the Midst of the Story: How Immersive Journalism Affects Our Perceptions and Cognitions." Cyberpsychology, Behavior, and Social Networking 20(11), November: 672-682.

Watson, Zillah. 2017. VR for News: The New Reality? Digital News Project. Oxford, UK: Reuters Institute for the Study of Journalism, Oxford University. https://reutersinstitute. politics.ox.ac.uk/our-research/vr-news-new-reality [Accessed 15 March 2020]. 